6. Качуровський Д. О. Світоглядна і морально-вольова підготовка як завдання виховної роботи у сучасному спортивному плаванні. Педагогіка, психологія та медико-біологічні проблеми фізичного виховання і спорту. Суми, 2012. № 2. С. 51-55.

7. Клименко В. В. Психологія спорту. Київ: 2007. 427 с.

8. Лубышева Л. И. Интеграция спортивного и олимпийского воспитания в образовательном пространстве школы. Наука 6 олимпийском спорте. Москва: 2007. № 2. С. 36-40.

9. Платонов В.Н. Система подготовки спортсменов в олимпийском спорте. Общая теория и ее практические приложения. Москва: $2005.820 \mathrm{c}$.

10. Платонов К. Занимательная психология. Санкт-Питербург: 1997. $288 \mathrm{c}$.

11. Степанов О. М., Фіцула М. М.. Основи психології і педагогіки: навчальний посібник. Київ: 2006. 520 с.

12. Тіняков А. О. Аналіз можливостей юнацького спорту як соціальної системи у вихованні моральних якостей особистості. Теорія і практика управління сочіальними системами: філософія, психологія, педагогіка, сочіологія. Київ: 2010. № 3. С. 66-74.

13. Цимбалюк I. М. Психологія : навч. посібник. Київ: 2004. 216 с.

DOI https://doi.org/10.30525/978-9934-26-041-4-5

\title{
РОЛЬ ПСИХОЛОГА У ПОСТРЕАБІЛІТАЦИЙНОМУ ЖИТТІ ОСІБ ІЗ НАРКОТИЧНОЮ ТА АЛКОГОЛЬНОЮ ЗАЛЕЖНІСТЮ
}

\author{
Козира П. В. \\ кандидат психологічних наук, \\ доиент кафедри психології факультету психології \\ Львівський державний університет внутрішніх справ \\ м. Львів, Украӥна
}

Реабілітація осіб із наркотичною та алкогольною залежністю процес ізоляції від зовнішнього середовища, зосередження особи на внутрішньому світі, переосмислення цінностей, напрацювання нових ресурсів для життя у тверезості. 
Це доволі узагальнене трактування процесу відмови від залежності, адже у кожного, хто звертається по допомогу власне уявлення стосовно вказаного вище діяння.

Та що ж все таки є спільним для всіх учасників реабілітації? Це безумовно потрапляння у певний «вакуум», адже процес реабілітації проходить за власними, чітко визначеними правилами, унеможливлює контакт особи із попереднім колом спілкування, висмикує із буденної рутини і звичного ритму життя, тим самим надаючи можливість по іншому поглянути на ті чи інші життєві ситуації, віднайти точку опори та, в певній мірі, «перезавантажитися».

Реабілітація може тривати від двадцяти восьми днів до декількох років. Тривалість цього періоду може залежати від безлічі речей, як наприклад: бажання учасника, досвід вживання, наявність тих чи інших проблем із законом, наявність часу...

Який висновок ми можемо зробити опираючись на часовий аспект процесу?

Час, відведений на реабілітацію, допомагає людині по новому почути себе, але з іншого боку цей час вибиває людину із життєвого ритму, як пагубного (процес вживання) так і продуктивного (соціальні ролі).

Якщо відмова від вживання це позитив, то вимушена відмова від виконання соціальних ролей тягне за собою негативні переживання особи і часто провокує коливання настрою та агресію. Але, на жаль, це вимушений крок, без якого неможливий успіх в подальшому.

Пройшовши процес реабілітації особа повертається у звичний ритм життя із певним набором знань, який, при бажанні та роботі над собою, допоможе оминати подразники та відслідковувати процеси зриву [1, с. 57].

Але так само як і у реабілітації так і у буденному постреабілітаційному житті роль психолога надзвичайно важлива. Якщо, під час проходження реабілітації, робота 3 психологом полягає у пропрацьовуванні переживань, вибудовуванні певної картини майбутнього, то у постреабілітаційному періоді роль психолога, окрім вказаного вище полягає ще й у підтримці вектора тверезого життя колишнього узалежненого.

У буденному житті особа, яка мала певні проблеми із алкоголем чи наркотиками та пройшла реабілітацію, вчиться жити по новому, без задоволення негативних чи позитивних переживань за допомогою вказаних вище речей.

Складність цього періоду також полягає в тому, що людина банально, може не знати інших джерел задоволення, оскільки все своє свідоме життя поруч із нею йшла залежність і всі соціальні ролі, навіть ті, які приносили невимовну радість, такі як, батько, чоловік, у цей час 
видаються чужими, емоційно виснажливими і такими, що провокують негатив та роздратування.

Описана вище ситуація притаманна усім, хто пройшов реабілітацію та повернувся у власне життя 3 бажанням бути тверезим. Першим часом в осіб присутня розсіяність, певна дезорієнтованість, адже вони починають дивитися на буденні речі, які супроводжувалися вживанням, тверезими очима. Щоденні кроки стають обережними, у кожній дії присутнє намагання прослідкувати причинно-наслідкові зв'язки, для того, щоб убезпечитися від минулого і не повернути його у теперішнє.

Перші місяці даються особливо важко, людина буквально заново починає вчитися їсти, проводити час 3 рідними, ходити вулицями, отримувати задоволення від прогулянок у парку чи катанні на велосипеді, вивчає власні відчуття під час прогулянки із сином чи розмови із дружиною. Здавалося б нічого нового, бо все це і так було у житті людини, але вище описані речі неодмінно у минулому супроводжувалися залежністю [2, с. 8].

Тому зараз, коли людина дивиться на своє звичне життя, у яке вона навіть не почала додавати щось нове чи робити щось кардинально по іншому, воно $\epsilon$ абсолютно іншим. Саме цей момент $\epsilon$ не менш стресовим та напруженим ніж процес реабілітації і роль психолога у ньому є не менш важливою. Адже людина повертається у «вільне» життя і хорошим варіантом підтримки та набуття впевненості у вибраному шляху може додати робота 3 психологом.

Психолог, бажано той самий, який брав участь у процесі реабілітації особи, організовує таку ж групову та індивідуально роботу, яка була у реабілітаційному центрі. Час обумовлюється та погоджується із всіма членами групи, але встановлюється у чіткому діапазоні. 3 метою більш комфортної комунікації можна створити спільноту чи групу у соціальній мережі, де у чаті заздалегідь обговорювати певні організаційні моменти. Окрім того чат $є$ також хорошим джерелом підтримки, адже у ньому кожен може писати власні думки, досвід чи навіть жартувати i y саркастичній формі висловлювати переживання та побоювання.

Психолог так само як інші члени групи у постреабілітаційному житті узалежненого відіграє дуже важливу роль, оскільки допомагає по новому навчитися базовим речам, а з урахуванням досвіду учасників під час проходження реабілітації, психолог - це та людина, яка зрозуміє, не осудить і допоможе набути додаткових ресурсів для життя у тверезості [3, с. 16].

Психолог - це той до кого узалежнений зможе прийти та не шукати потрібних слів, а зможе без лишніх «фільтрів» озвучити власні переживання. Колишні узалежнені, які так само приходять на групу 26 
це такі ж люди, які об'єднані спільною проблемою і тривожна ситуація одного може абсолютно достеменно перегукуватися із такою ж ситуацією іншого, перемога одного може допомогти відкрити шлях іншому, сумніви одного можуть розвіятися за допомогою настирності решти і звісно ж організаторські здібності у цьому процесі належать не кому іншому, як психологу.

\title{
Література:
}

1. Громадська спілка «Міжнародна антинаркотична асоціація». Комплексна програма реабілітації осіб 3 хімічної та нехімічної залежності. - Київ. - 2014. - 173 с.

2. Постанова Кабінету міністрів України від 04.10.2017 № 741 ««Про затвердження типових положень про заклади соціальної підтримки сімей, дітей та молоді» - Режим доступу: https://zakon.rada.gov.ua/laws/show/741-2017-\%D0\%BF\#Text

3. Відновлення. Звільнення від наших залежностей / Расселл Бренд; пер. $з$ англ. М. Коваленко. - Дніпро: Моноліт, 2020. 304 с.

\section{DOI https://doi.org/10.30525/978-9934-26-041-4-6}

\section{ОСОБЛИВОСТІ КОНФЛІКТНОСТІ ПРАЦІВНИКІВ ДСНС УКРАЇНИ 3 РІЗНИМ РІВНЕМ ОСОБИСТІСНОЇ АВТОНОМІЇ}

\author{
Сергіснко Н. П. \\ кандидат психологічних наук, доцент, \\ дочент кафедри психології діяльності в особливих умовах \\ сочіально-психологічного факультету \\ Національний університет циивільного захисту Украӥни \\ Свічкар М. О. \\ магістр соиіально-психологічного факультету \\ Національний університет цивільного захисту Украӥни \\ м. Харків, Україна
}

Актуальність проблеми. Проблема автономії, тобто незалежності, існувала, мабуть, стільки, скільки існує людство. 3 філософської точки зору, автономія - це принцип самостійності буття, що направляється 